\title{
Use of Compost Instead of Chemical Fertilizer to Avoid Fluorine Contamination of Soil, Water, and Food
}

\author{
by \\ Albert SCHATZ* and Vivian SCHATZ*
}

This report discusses certain kinds of pollution caused by chemical fertilizers. It also considers how these problems may be minimized or avoided by using compost instead of chemical fertilizers. Particular attention is devoted to fluorine contamination because this element, which is present in phosphatic fertilizers, is a health hazard. That is why the Swedish Parliament, on November 18, 1971, revoked the law allowing communities to fluoridate their drinking water. Fluorine is, among other things, a carcinogen. It is therefore important to minimize our total daily fluorine intake. A more extensive use of compost can help us do that because it has a very low fluorine content.

\section{Eutrophication and Cancer}

Nitrogen and phosphorus in chemical fertilizers have been receiving increasing attention because these elements are responsible for certain cases of eutrophication. This is a problem that occurs when some of that nitrogen and phosphorus is leached out of the soil and ends up in ponds and lakes.

Nitrogenous fertilizers are also responsible for methemoglobinemia. This is a disease resulting from high concentrations of nitrate in food and drinking water. Much of that nitrate comes from fertilizers. Bacteria in the gut convert nitrate to nitrite. Secondary and tertiary amines which are formed when food is cooked, react with nitrite to produce nitrosamines. These are carcinogenic compounds which may be responsible for human cancer[1,2].

\section{Contamination of Soil by Fluorine}

The use of superphosphate fertilizer creates another kind of problem because of the fluorine it contains. The application of 1000 pounds of superphosphate to an acre adds approximately 17.5 pounds of fluorine. That increases by about $7.5 \mathrm{ppm}$ the fluorine content of the soil to plow depth. One thousand pounds of rock phosphate add about twice as much fluorine[3,4,5].

* Temple University, Philadelphia, Pennsylvania; and Radburn Research Institute, Fair Lawn, New Jersey.

This article, originally appearing elsewhere, is reproduced here through the courtesy of the authors (Editor). 
In 1970, two Soviet soil scientists reported that "regular application of superphosphate during 35 years increased the content of fluorine in a chernozem" soil and in "plants" grown on that soil. They concluded that "this may result in a decrease of . . . productivity" of several crops, "particularly maize."[6]

Their report directed our attention to fluorine as a contaminant of soil, of water passing through that soil, and of food grown on that soil. We then found that, in 1946, Robinson and Edgington at the U. S. Department of Agriculture reported that fluorine accumulated in every one of four New Jersey soils fertilized with superphosphate for 23 to 40 years (Table 1)[5]. The increases in fluorine content of the surface soils and subsoils ranged from $36 \%$ to $96 \%$ and from $13 \%$ to $39 \%$, respectively. The average increases for the four surface and subsoils were $64 \%$ and $25 \%$, respectively.

\section{Contamination of Water by Fluorine}

In 1943, researchers at the University of Wisconsin studied the effect of superphosphate and rock phosphate fertilizers on the amount of fluorine in drainage water[3,4]. Their findings (Table 2) show that relatively large amounts of fluorine from both rock phosphate and superphosphate escape into the drainage water. In one case, the drainage water contained $1.7 \mathrm{ppm}$ fluorine. This approached the $2.0 \mathrm{ppm}$ level which causes mottled enamel. That is the earliest symptom of fluorine toxicity. Under certain conditions, the drainage water could contain as much as $6.3 \mathrm{ppm}$ fluorine.

The Wisconsin scientists concluded that "when phosphate fertilization is carried on over many years, very considerable quantities of highly toxic fluorine will have been added to the soil"'[4] "The fact remains," they stated, "that dangerously high concentrations of fluorine are possible in the drainage water from fields bountifully supplied with phosphate fertilizer.'[4] Their "data," they also said, "raise the question whether our present system of soil fertilization with fluorine-carrying phosphates may lead to a contamination of drinking waters to a point where they may become dangerous to human health',[3].

\section{Contamination of Food by Fluorine}

Robinson and Edgington, at the U. S. Department of Agriculture, studied the amounts of fluorine in 28 plant products grown on a "Virginia . . . soil . . . liberally supplied with superphosphate for about 15 years"[5]. They considered spinach and young poke shoots to be "fluorine accumulators" because these plants contained 28.3 and $42.3 \mathrm{ppm}$ of fluorine, respectively. Lettuce and parsley both contained 11.3 ppm fluorine. Despite these high findings, they concluded "that there is very little chance of fluorine contamination'"[5].

In Japan, Okamura and Matsuhisa reported an alarming increase of fluorine in some common foods grown in the district of Aichi in 1965 compared to 1958[7]. Their findings are presented in Table 3. During that seven-year period, the fluorine content of pumpkin, green tea, water melon, and lotus rhizome increased $429 \%, 575 \%$, $831 \%$, and $976 \%$, respectively.

Table 4 shows the total daily fluorine consumption in the district of Aichi in 1958 
and 1965. Within those seven years, the per capita fluorine intake from water, food, and tea increased from 3.21 to 8.82 milligrams per day. That is a $175 \%$ increase.

Some investigators have claimed that fluorine does not wash out of soils, does not accumulate in plants, and does not produce harmful effects. But that is an oversimplification. What happens when fluorine is added to the soil depends on such factors as the form in which it is applied, the amount of fluorine, how much lime and phosphate are present, the species of plants grown, and the soil type and its geology.

Table 1

Fluorine content of New Jersey soils heavily fertilized with superphosphate over long periods of time compared to similar soils nearby that were not fertilized

\begin{tabular}{lccccc}
\hline \multirow{2}{*}{ Soil } & Fertilized, & \multicolumn{2}{c}{ Depth, inches } & \multicolumn{2}{c}{ Fluorine, ppm } \\
\cline { 3 - 6 } & years & Surface soil & Subsoil & Surface soil & Subsoil \\
\hline $\begin{array}{l}\text { Sassfras } \\
\text { gravelly } \\
\text { sandy } \\
\text { loam }\end{array}$ & 0 & $0-5$ & $7-14$ & 44 & 46 \\
& $23+$ & $0-8$ & $8-12$ & 70 & 64 \\
\hline $\begin{array}{l}\text { Sassafras } \\
\text { loam }\end{array}$ & 0 & $1-6$ & $12-18$ & 114 & $(40)^{*}$ \\
\hline $\begin{array}{l}\text { Weathersfield } \\
\text { loam }\end{array}$ & 30 & $0-6$ & $10-14$ & 188 & 120 \\
& 0 & $1-5$ & $7-12$ & 150 & 138 \\
& 40 & $0-8$ & $12-16$ & 294 & $(16)$ \\
\hline $\begin{array}{l}\text { Collington } \\
\text { sandy } \\
\text { loam }\end{array}$ & 0 & $0-4$ & $6-14$ & 66 & 194 \\
\hline \begin{tabular}{l} 
Average increase \\
\hline
\end{tabular} & 40 & $0-6$ & $8-12$ & 90 & $(13)$ \\
\hline
\end{tabular}

* Data in parentheses are $\%$ increase of fluorine.

Table 2

Fluorine content of drainage waters from Tennessee soils receiving phosphatic fertilizers from 1930 to 1933

\begin{tabular}{llc}
\hline Time of analysis & \multicolumn{1}{c}{ Treatment } & $\begin{array}{c}\text { Fluorine (ppm) in } \\
\text { drainage water }\end{array}$ \\
\hline Jan. 1934 & None (control) & 0.044 \\
& Superphosphate & 0.084 \\
May 1934 & Rock phosphate* & 1.710 \\
& None (control) & 0.050 \\
& Superphosphate & 0.106 \\
& Rock phosphate* & 0.118 \\
\hline
\end{tabular}

* The rock phosphate added 53.7 pounds of fluorine per acre. 
Table 3

Fluorine content of common foods produced in 1958 and 1965 in the district of Aichi, Japan

\begin{tabular}{|c|c|c|c|}
\hline \multirow[t]{2}{*}{ Food } & \multicolumn{2}{|c|}{ Fluorine, ppm } & \multirow{2}{*}{$\begin{array}{c}\text { Increase, } \\
\%\end{array}$} \\
\hline & 1958 & 1965 & \\
\hline \multicolumn{4}{|l|}{ Unpolished rice } \\
\hline Glutinous & 6.19 & $9.98(1960)^{*}$ & 61.2 \\
\hline Non-glutinous & 5.73 & $14.50(1964)^{*}$ & 153.0 \\
\hline Barley & $8.95(1962) *$ & 10.01 & 11.8 \\
\hline Wheat & 5.17 & 8.50 & 64.4 \\
\hline Pumpkin & 1.10 & 5.82 & 429.0 \\
\hline Watermelon & 0.48 & 4.47 & 831.0 \\
\hline Lotus rhizome & 1.72 & 18.51 & 976.0 \\
\hline Buterbur & 1.01 & 1.82 & 80.0 \\
\hline Green tea & 88.75 & 599.50 & 575.0 \\
\hline \multirow[t]{2}{*}{ Average } & 3.79 & 9.20 & 325.8 \\
\hline & & & $353.5 \dagger$ \\
\hline
\end{tabular}

* Years in parentheses are other than 1958 and 1965.

* These averages do not include the values for green tea.

$\uparrow$ This average includes the value for green tea.

Table 4

Average total daily per capita consumption of fluorine from water, food, and tea in the district of Aichi, Japan, in 1958 and 1965*

\begin{tabular}{lcccc}
\hline & \multicolumn{2}{c}{1958} & & 1965 \\
\hline Season & Shippo & Yatomi & Average for Aichi \\
\cline { 2 - 3 } & mg. & mg. & mg. \\
Spring & 3.21 & 1.94 & 8.97 \\
Summer & 3.38 & 2.25 & 6.62 \\
Autumn & 4.35 & 3.08 & 8.56 \\
Winter & 4.38 & 3.10 & 11.13 \\
\hline Averate & 3.83 & 2.59 & \\
& & 3.21 & & 8.82 \\
\hline
\end{tabular}

* Shippo and Yatomi are two rural villages in the district of Aichi. Shippo is an area with mottled enamel.

\section{Fluorine and Cancer}

Okamura and Matsuhisa became interested in fluorine as a result of their research on the geographical distribution of mortality due to gastric cancer[7]. They found a correlation between fluorine content of rice and death rates for gastric cancer. There were also geographical and annual correlations between these death rates and the amounts of phosphatic fertilizers applied to rice paddies. The fertilizers used contained 0.01 to $9.88 \%$ fluorine. 
Okamura and Matsuhisa also found that the 1960 death rates from gastric cancer correlated with the fluorine content of "Miso" in 28 prefectures of Japan[8]. "Miso" is a fermented product made from rice and soybeans.

Our analysis of official health statistics from Birmingham, England, show that the death rates from leukemia and from all types of cancer were significantly greater from 1958 to 1964[9,10]. Artificial fluoridation of the drinking water of Birmingham was begun in June of 1964. "The amount" of fluorine "added was increased gradually and reached a concentration of one part per million by the end of the year"'[11]. Thus there were more deaths from cancer after fluoridation, than before.

As recently as 1970, Soviet investigators expressed concern about the possibility that fluorine in drinking water might cause cancer[12].

In 1965, Taylor and Taylor found that fluorine and other halogens accelerated "the growth of tumor transplants in mice and embryonated eggs"[13]. As little as 1.0 $\mathrm{ppm}$ of sodium fluorine in the drinking water stimulated growth of tumor transplants in mice.

Fluorine also produced deformities in toad embryos[14] and melanotic tumors in Drosophila[15]. Finally, fluorine caused "a consistent and highly significant increase" in "the production of recessive lethal mutations by X-rays in Drosophila sperm"[16]. These and other reports validate Alexander Levitt's warning, in 1948, that fluorine and other halogens "may be responsible for geographic or regional occurrences of" several "diseases, including cancer"[17].

\section{What Compost Offers}

If less chemical fertilizer is used, other materials will have to provide soils with the nitrogen, phosphorus, and potassium which plants require. To meet that need, we can, for example, use human wastes, as is already being done on a large scale in China. Robert Rodale has calculated that "a million adult human beings produce in a year $5,794,300$ pounds of nitrogen, $1,825,000$ pounds of potsssium, and 775,600 pounds of phosphorus"[18]. He then pointed out: "We flush that wealth down the drain at our peril. We just can't afford the luxury of throwing away large quantities of wonderful fertilizer and organic matter, which our soils need desperately."

Garbage and other organic wastes are additional sources of the three major plant nutrients and trace elements. All these materials can be composted, and the resulting humus added to the soil. The large-scale use of compost for that purpose would minimize or avoid the problem of fluorine contamination which phosphatic chemical fertilizers create. In an official U. S. Department of Agriculture publication, Fox et al. point out that "for . . . animal feed supplement . . . the primary objective is the production of fluorine-free phosphate. But for fertilizer purposes, the objective is to make the phosphorus agronomically available without regard to fluorine."[19] Our attitude is just the opposite. We believe that fluorine in phosphatic fertilizers must be given the most serious consideration because fluorine is a carcinogen and a health hazard in many other ways.

\section{What Will It Cost?}

One might raise the objection that it will cost too much to produce and use 
compost in place of chemical fertilizers. But that is not true from an overall point of view. One must, for example, take into account the economic loss incurred as a result of the death of Lake Erie. How much are we paying for eutrophication there and elsewhere? How can we estimate the cost of methemoglobinemia due to excessive nitrate in food and drinking water? What dollar values can be placed on cancer that may be caused by nitrosamines and the fluorine which derive from chemical fertilizers.

Such hidden costs are usually disregarded in comparing the economics of compost versus chemical fertilizers. But when these hidden costs are taken into account, compost is far less expensive than chemical fertilizers.

\section{References}

[1] Phillips, W. E. J. Nitrate content of foods. Public health implications. Canadian Inst. of Food Technol. Jour. 1-98-103, 1968.

[2] Lijinsky, W., and Epstein, S. S. Nitrosamines as environmental carcinogens. Nature 225:21-23, 1970.

[3] Hart, E. B., Phillips, P. H., and Bohstedt, G. Relation of soil fertilization with superphosphates and rock phosphate to fluorine content of plants and drainage waters. Amer. Jour. Publ. Health 24:936-940, 1934.

[4] Does fluorine in phosphorus fertilizers endanger the public health? pp. 125-127. In Science Safeguards: Crops, Livestock, Farm Income. 51st Annual Report, 1933-1934. Wisconsin Agr. Expt. Sta. Bull. No. 430 (1935).

[5] Robinson, W. O., and Edginton, G. Fluorine in soils. Soil Science 61:341-353, 1946.

[6] Kudzin, Yu. K., and Pashova, V. T. Fluorine content in soil and plants after prolonged application of fertilizers. Pochvovedeniye (U.S.S.R.) 2:74-79, 1970.

[7] Okamura, T., and Matsushisa, T. The fluorine content in favorite foods of Japanese. Japanese Jour. Publ. Health 14:41-47, 1967.

[8] Okamura, T., and Matsuhisa, T. Studies on fluorine and other related components of Japanese foods. Part B: Fluorine and salt contents of "Miso" and other foods rich in salt, and their geograhipcal correlation with mortality from gastric cancer. Jour. Japanese Soc. Food and Nutrition 18:253-257, 1965.

[9] Report of the Medical Officer of Health for the Year 1968. City of Birmingham (England).

[10] Personal communication of October 27, 1970, from Dr. E. L. M. Millar, Medical Officer of Health. Birmingham, England.

[11] Personal communication of October 19, 1970, from Dr. E. L. M. Millar, Medical Officer of Health. Birmingham, England.

[12] Gabovich, R. D., and Tsiprian, V. I. Study of the action of fluorine in drinking water. A sanitarygerontological test. Gig. Sanit. (U.S.S.R.) 35:34-40, 1970.

[13] Taylor, A. Effect of sodium fluoride on tumor growth. Proc. Soc. Exptl. Biol. \& Med. 119: $119: 252-255,1965$.

[14] Kawahara, H., and Kawahara, K. Preliminary report on the influence of NaF solution upon the early development of toad embryos. Tokushima Jour. Exptl. Med. 1:98-104, 1954. (Abstracted in English in Fluoride 4:167-171, 1971.)

[15] Rapaport, I. Oligophrenie mongolienne et caries dentaires. Revue de Stomatologie (Paris) 46:207-218, 1963.

[16] Mukherjee, R. N., and Sobels, F. H. The effects of sodium fluoride and iodoacetamide on mutation induction by X-irradiation in mature spermatozoa of Drosophila. Mutation Research 6:217-225, 1968.

[17] Levitt, A. The halogen elements in relation to autonomic dysfunctions and degenerative diseases, including cancer. Jour. Amer. Osteopathic Assoc. 47:559-567, 1948.

[18] Rodale, R. Goodbye to the flush toilet. Compost Science 12:24-25, 1971. 
[19] Fox, E. J., Stinson, J. M., and Tarbutton, G. Fluorine: Emission and Recovery. Chapter 10 (pp. 217-250) in Superphosphate: Its History, Chemistry, and Manufacture. U. S. Dept. of Agriculture. Washington, D.C. 1964. 